\title{
PROGRAM CORPORATE SOCIAL RESPONSIBILITY PT PERTAMINA REFINERY UNIT VI BALONGAN DALAM MENINGKATKAN KEBERDAYAAN MASYARAKAT (Kasus Pada Desa Balongan, Majakerta, Sukaurip dan Karangsong)
}

\author{
llona V. Oisina Situmeang \\ ilonaoisina@yahoo.com \\ Universitas Persada Nusantara, YAI, Jakarta
}

\begin{abstract}
The Government requires that any company operating in Indonesia to undertake CSR programs for the surrounding community, which programs are not only charity but also to empower communities, so that the surrounding communities be empowered; and this has been done by PT Pertamina Balongan. This study used a qualitative approach that is descriptive. Primary data collection is done by in-depth interviews and group discussions while secondarily conducted through the study of literature. The result is that Pertamina conducting activities in various areas of public life, including in the field leads to more social charity activities, in economics with a focus on community development activities needed by the community and in the environmental field is directed to a cleaner environment and comfortable as it may improve the quality of life as well as in the field of religion and education. This activity is routinely maintained by Pertamina by listening to the key needs of the community.
\end{abstract}

Keywords: Corporate Social Responsibility (CSR), People Empowerment, Charity, Clean Environment

\begin{abstract}
Abstrak
Pemerintah mewajibkan setiap perusahaan yang beroperasi di Indonesia untuk melakukan program CSR bagi masyarakat sekitar, dimana program yang dilakukan tidak hanya sekedar perbuatan amal namun lebih kepada pemberdayaan masyarakat, sehingga masyarakat sekitar menjadi berdaya. Hal ini sudah dilakukan oleh PT Pertamina Balongan. Penelitian ini menggunakan pendekatan kualitatif yang bersifat deskriptif. Pengumpulan data primer dilakukan dengan wawancara mendalam dan diskusi kelompok sedangkan data sekunder dilakukan dengan studi literatur. Hasil yang diperoleh bahwa Pertamina melakukan kegiatan di berbagai bidang kehidupan masyarakat, yaitu bidang sosial lebih mengarah kepada kegiatan amal, di bidang ekonomi fokus pemberdayaan masyarakat dengan berbagai kegiatan yang dibutuhkan oleh masyarakat dan dibidang lingkungan mengarah kepada lingkungan yang bersih, nyaman dan dapat meningkatkan kualitas hidup serta di bidang agama dan pendidikan. Kegiatan ini rutin dilakukan Pertamina dengan mendengarkan kebutuhan-kebutuhan utama dari masyarakat.
\end{abstract}

Kata kunci: CSR, Tanggung Jawab Sosial Masyarakat, Pemberdayaan Masyarakat, Amal, Lingkungan Bersih

\section{Pendahuluan}

Kehadiran perusahaan dalam suatu wilayah merupakan salah satu bukti bahwa wilayah tersebut memiliki potensi baik secara ekonomi, sosial budaya, sumberdaya alam dan sumberdaya lainnya, sehingga diharapkan menimbulkan efek pengganda positif bagi masyarakat sekitar. Disayangkan, jika kehadiran perusahaan justru menghilangkan 
potensi sesungguhnya dan membangun jurang pemisah antara masyarakat dengan perusahaan. Untuk menghilangkan jurang pemisah tersebut perlu dilakukan komunikasi yang efektif, sehingga terjalin komunikasi dan interaksi antara perusahaan dengan masyarakat, sehingga dapat hidup secara berdampingan dan saling menguntungkan. Berangkat dari pemikiran tersebut, perusahaan berlomba-lomba untuk hadir di tengah masyarakat melalui berbagai kegiatan sosia serta pengembangan dan pemberdayaan masyarakat. Untuk menghindari kesenjangan sosial antara perusahaan dan masyarakat dapat dilakukan dengan suatu kepedulian perusahaan dalam bentuk program Corporate Social Responsibility (CSR). Melalui program CSR ini diharapkan dapat mempererat hubungan antara perusahaan dengan masyarakat.

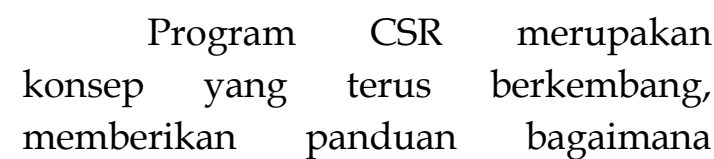
sebuah organisasi berinteraksi dengan masyarakat dan lingkungan sosialnya. Secara umum, menurut Carr et al., (2004) CSR dipahami sebagai cara organisasi dalam mengintegrasikan kepentingan sosial, lingkungan hidup dan ekonomi dalam nilai-nilai budaya, pengambilan keputusan, strategi dan operasi organisasi dengan cara yang transparan dan dapat dipertanggungjawabkan. Implementasi berbagai aspek tersebut akan dapat meningkatkan kehidupan sosial masyarakat.

Dalam pelaksanaannya banyak kegiatan CSR yang bias. Kegiatan yang dilakukan seringkali hanya bagian dari kegiatan promosi produk atau perusahaan yang sifatnya jangka pendek. Seringkali dalam praktiknya program CSR hampir disamakan dengan derma (charity), sehingga ketika perusahaan membagi-bagikan hadiah kepada masyarakat di sekitar, perusahaan sudah dianggap melaksanakan program CSR kepada masyarakat. Kegiatan derma (charity) ini dapat menyebabkan masyarakat menjadi bergantung pada perusahaan. Hal tersebut menyebabkan tidak ada manfaat yang berkelanjutan yang dirasakan masyarakat. Sesungguhnya, konsep CSR tidak sama dengan derma (charity) atau kedermaan (philanthropy) yang lebih spontan pemberian dan tidak memiliki efek jangka panjang bagi masyarakat. Dalam arti tidak terjadi pemberdayaan masyarakat secara maksimal untuk meningkatkan kualitas hidup masyarakat.

Program CSR yang dijalankan oleh perusahaan hendaknya dilakukan dengan mempertimbangkan berbagai aspek kehidupan sehingga memiliki manfaat jangka panjang bagi penerimanya. Menurut Widiyanarti (2005), pendekatan CSR hendaknya dilakukan secara holistic. Artinya, pendekatan yang dilakukan oleh perusahaan tidak dalam kegiatan bisnis semata, melainkan juga bergerak dari yang sifatnya derma (charity) menuju ke arah CSR yang lebih menekankan pada keberlanjutan pengembangan masyarakat (community development). Intinya, bagaimana melalui program CSR, masyarakat menjadi berdaya, baik secara ekonomi, sosial budaya, lingkungan hidup secara berkelanjutan (sustainability) sehingga perusahaan juga dapat terus berkembang dengan dukungan masyarakat sekitar. Dalam 
konteks ini, CSR lebih dimaknai sebagai investasi jangka panjang bagi perusahaan yang melakukannya.

Penerapan kegiatan CSR di Indonesia berbeda-beda, tergantung kepada kebijakan, visi dan misi serta budaya di masing-masing perusahaan. Guna berhasilnya pelaksanaan kegiatan tersebut perlu kesinergian antara perusahaan, pemerintah dan masyarakat, sehingga kehadiran perusahaan menjadi perekat dan memiliki nilai positif untuk meningkatkan keberdayaan masyarakat. Program CSR harus mampu untuk mendukung perusahaan meminimalkan dampak negatif yang ditimbulkan akibat kegiatan operasinya serta memaksimalkan dampak positifnya kepada masyarakat. Salah satu perusahaan yang sudah melaksanakan kegiatan CSR yang berbasis pemberdayaan adalah PT Pertamina Balongan.

PT Pertamina Refinery Unit VI Balongan merupakan salah satu dari tujuh Refinery Unit PT Pertamina yang beroperasi di Indonesia. Divisi yang menangani program CSR adalah Divisi Hubungan Pemerintah dan Masyarakat (Hupmas). PT Pertamina melakukan berbagai kegiatan sebagai sebuah keharusan perusahaan untuk masyarakat sekitar yang tujuannya adalah untuk meningkatkan kualitas hidup masyarakat sekitar perusahaan melalui berbagai kegiatan pemberdayaan. Hal ini yang membuat penulis tertarik untuk meneliti tentang program CSR yang dilakukan oleh PT. Pertamina Balongan apakah bermanfaat untuk meningkatkan keberdayaan bagi masyarakat sekitar perusahaan atau belum tepat sasaran.
Masalah penelitian ini adalah: “Bagaimana program CSR PT. Pertamina Refinery unit VI Balongan Dalam meningkatkan keberdayaan masyarakat (kasus pada desa Balongan, Majakerta dan Karangsong)?" Dengan mengetahui Program CSR tersebut, penelitian ini diharapkan dapat memberikan kegunaan secara spesifik baik secara teoritis maupun secara praktis. Secara teoritis, penelitian ini diharapkan dapat memberikan kontribusi pada pengembangan ilmu komunikasi khususnya kegiatan hubungan masyarakat (humas) mengenai program CSR perusahaan untuk masyarakat lokal. Mengembangkan dan menyempurnakan secara empiris teori komunikasi pembangunan yang dikaitkan dengan pemberdayaan masyarakat, mengkaji tentang program kegiatan CSR dalam mendukung program pemberdayaan masyarakat. Secara praktis bagi Perusahaan, penelitian ini dapat memberikan kontribusi kepada PT Pertamina Balongan untuk meningkatkan kemampuan perusahaan dalam memahami pentingnya program CSR yang dilakukan perusahaan secara berkesinambungan dan tepat sasaran dalam memberdayakan masyarakat lokal.

\section{Tinjauan Pustaka}

\section{Corporate Social Responsibility}

Seiring dengan peradaban modern eksistensi suatu perusahaan atau dunia usaha terus menjadi sorotan. Salah satu isu penting yang masih terus menjadi perhatian dunia usaha hingga saat ini adalah CSR sebagai bagian dari konfigurasi hubungan antara dunia 
bisnis dan masyarakat, persoalan CSR mengalami rumusan konseptual yang terus berubah, sejalan dengan perkembangan yang dialami oleh dunia usaha itu sendiri. Pada awalnya dan untuk waktu yang sangat panjang, dunia usaha barang kali tidak perlu atau tidak pernah berfikir mengenai CSR. Hal ini karena proposi teori klasik, sebagaimana dirumuskan oleh Adam Smith tugas korporasi diletakkan semata-mata mencari keuntungan, "the only duty of the corporation is to make profit. Motivasi utama setiap perusahaan atau industri atau bisnis adalah meningkatkan keuntungan (Djalil, 2003).

Secara perlahan ideologi "the only duty of the corporation is to make profit" yang dianut oleh korporasi telah berubah dengan munculnya kesadaran kolektif bahwa kontiunitas pertumbuhan dunia usaha tidak akan terjadi tanpa dukungan yang memadai dari stakeholder yang melingkupinya seperti, manajer, konsumen, buruh dan anggota masyarakat. Inti dari pandangan ini adalah bahwa dunia usaha tidak akan sejahtera jika stakeholdernya juga tidak sejahtera.

Banyak istilah yang digunakan secara bergantian untuk kegiatan TSP, kewarganegaraan korporat (corporate citizenship), ada juga yang menamakan corporate community relationship, ada juga yang menyebutnya organisasi berkelanjutan (Iriantara, 2004).

Petkoski dan Twose (2003) mendefinisikan CSR sebagai komitmen bisnis berperan untuk mendukung pembangunan ekonomi, bekerjasama dengan karyawan dan keluarganya, masyarakat lokal dan masyarakat luas, untuk meningkatkan mutu hidup mereka dengan berbagai cara yang menguntungkan bagi bisnis dan pembangunan.

Elkington dalam Wibisono (2007), mengembangkan konsep Triple bottom lines dalam istilah economic properity, environmental quality, social justice. Perusahaan yang ingin berkelanjutan harus memikirkan 3P (profit, people, planet), yaitu selain mengejar keuntungan (profit), perusahaan juga harus memperhatikan dan terlibat pada pemenuhan kesejahteraan masyarakat (people) dan turut berkontribusi aktif dalam menjaga kelestarian lingkungan (planet).

Penelitian Iryani (2009) mengatakan bahwa triple bottom lines merupakan suatu konsekuensi dari definisi sustainable development yang mana mempunyai tiga elemen penting yaitu pertumbuhan ekonomi, perlindungan lingkungan dan kesejahteraan sosial, terlihat pada gambar 1.

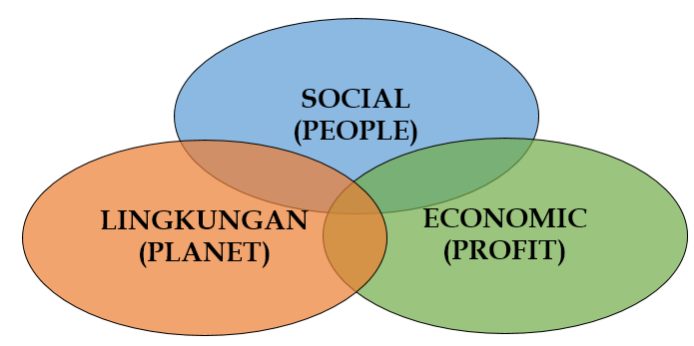

Gambar 1. Triple Bottom Lines dalam kegiatan tanggungjawab sosial Perusahaan (Iryani, 2009)

Penelitian Pfleiger dalam Machiavelli (2011), menunjukkan bahwa usaha-usaha pelestarian lingkungan oleh perusahaan akan mendatangkan sejumlah keuntungan, diantaranya 
adalah ketertarikan pemegang saham dan stakeholders terhadap keuntungan perusahaan akibat pengelolaan lingkungan yang bertanggungjawab. Hasil lain mengindikasikan bahwa pengelolaan lingkungan yang baik dapat menghindari klaim masyarakat dan pemerintah serta meningkatkan kualitas produk yang pada akhirnya akan dapat meningkatkan keuntungan ekonomi. Sebagian perusahaan dalam industri modern menyadari sepenuhnya bahwa isu lingkungan dan sosial juga merupakan bagian penting dari perusahaan.

Menurut riset yang dilakukan oleh Nursahid (2006) mengatakan pelaksanaan program CSR di Indonesia akhir-akhir ini cukup intens diperbincangkan oleh berbagai kalangan seperti pemerintah, pebisnis, akademisi dan LSM. Namun demikian riset-riset yang terkait dengan implementasi tanggungjawab sosial perusahaan belum banyak dilakukan, khususnya terkait dengan implementasi CSR yang berbasis pada pemberdayaan masyarakat dan modal sosial.

Banyak kalangan melihat bahwa praktik CSR yang dilakukan masih sebatas "kosmetik". Nuansa kosmetik tersebut menurut Wibisono (2007) tercermin dari berbagai aspek sejak perumusan kebijakan dan penentuan orientasi program, pengorganisasian, pendanaan, eksekusi program, hingga evaluasi dan pelaporan. Diharapkan dalam melakukan program CSR dapat memperkuat kembali modal sosial komunitas lokal sehingga pemberdayaan masyarakat dalam bidang ekonomi, sosial dan budaya dapat tercapai.

\section{Penerapan Tanggungjawab Sosial Perusahaan di Badan Usaha Milik Negara (BUMN)}

Praktik CSR oleh Badan Usaha Milik Negara (BUMN) ini menarik untuk dikaji disebabkan oleh faktor pembeda yang secara normatif mendukung kegiatan kedermawanan sosial BUMN ini seharusnya dapat berkembang, Pertama, karena sifat dan statusnya sebagai perusahaan milik negara, BUMN tidak terkendala oleh motif pengurangan pajak (tax deduction) sebagaimana menjadi pengharapan perusahaan-perusahaan swasta. Kendati pajak tetap merupakan kewajiban bagi BUMN, kewajiban ini tidak serta merta mempengaruhi kelancaran kegiatan atau operasi BUMN. Kedua, terdapat instrument "pemaksa" berupa kebijakan pemerintah; dimana melalui Kepmen BUMN Nomor: Kep-236/MBU/2003, perusahaan BUMN menjalankan Program Bina Lingkungan (PKBL), sehingga dengan praktik derma yang imperatif tersebut dimungkinkan bahwa potensi rata-rata sumbangan sosial perusahaan-perusahaan BUMN lebih besar dari perusahaan-perusahaan swasta (Nursahid, 2006).

Badan Usaha Milik Negara merupakan salah satu elemen utama kebijakan ekonomi strategis negaranegara berkembang. Keberadaan BUMN mempunyai pengaruh utama dalam pembangunan negara-negara dunia ketiga. Setidaknya, BUMN diperlukan dalam pengaturan infrastruktur dan public utilities, dan menempatkan dirinya untuk berperan pada hampir seluruh sektor aktivitas ekonomi (Nursahid, 2006). 
Pasal 11, ayat 3, huruf $\mathrm{p}$ Undang Undang Nomor 22 Tahun 2001 tentang minyak dan gas bumi mengamanatkan bahwa setiap perusahaan minyak dan gas bumi pemegang kontrak kerjasama pengusahaan minyak dan gas bumi di suatu wilayah wajib melakukan pengembangan masyarakat sekitarnya dan menjamin hak-hak masyarakat adat. Pada pasal 42, huruf k menyatakan bahwa pengawasan yang dilakukan atas dasar wewenang dan tanggung jawab dari instansi terkait meliputi pengembangan lingkungan dan masyarakat setempat.

Berdasarkan UU No 22 tahun 2001 tersebut perusahan-perusahaan minyak dan gas bumi yang beroperasi di Indonesia melaksanakan program CSR, baik dalam bentuk community development. Meski demikian, pada umumnya tidak berjalan secara terencana dan terpadu dalam suatu program yang berkelanjutan. Hal ini sangat bergantung pada visi, misi dan budaya korporat dari suatu perusahaan. Hal ini diperkuat pendapat Susanto (2007b) undang-Undang Perseroan Terbatas mewajibkan perusahaan yang berbasis sumberdaya alam menyisihkan anggaran untuk CSR dan lingkungan. Maksud munculnya ketentuan ini tentu dilandasi oleh keinginan yang mulia. Tetapi antara niat, aturan dan pelaksanaan di lapangan acap berbeda. Perdebatan banyak terjadi diseputar kegiatan CSR yang seharusnya berlandaskan kerelaan, tetapi menjadi kewajiban. Tetapi karena sudah menjadi UU, yang bisa dilakukan adalah justru bagaimana merumuskan dalam peraturan pemerintah yang akan menjadi juklaknya.
PT Pertamina merupakan salah satu industri minyak dan gas bumi di Indonesia. Industri minyak dan gas bumi selalu dihubungkan dengan kegiatan ekspoitasi sumberdaya alam yang tidak terbarukan. Eksploitasi sumberdaya alam tidak terbarukan yang berlangsung pada suatu generasi guna mengejar kemakmuran akan menghilangkan kesempatan bagi generasi yang akan datang untuk mengejar kemakmuran yang sama. Oleh karena itu dalam mengelolah sumberdaya alam migas hendaknya tetap memberdayakan dan memajukan masyarakat pada daerah yang dikelolah sumberdaya alamnya sebagai efek ganda dari adanya eksploitasi dan pengelolahan migas di daerah Balongan.

Dalam konteks ini pengelola yaitu PT Pertamina Balongan mempunyai CSR kepada masyarakat setempat. Program CSR yang diperuntukkan sebagai komitmen bisnis perusahaan dan berkontribusi dalam pembangunan ekonomi berkelanjutan dengan cara memberdayakan serta memberikan peluang kepada masyarakat untuk berpartisipasi dalam pembangunan guna memberdayakan masyarakat serta meningkatkan kemandirian bagi masyarakat Balongan.

\section{Pemberdayaan Masyarakat}

Istilah pemberdayaan (empowerment) berasal dari kata "power" yang berarti kemampuan, tenaga, atau kekuasaan. Dengan demikian, secara harfiah pemberdayaan dapat diartikan sebagai peningkatan kemampuan, tenaga, kekuatan, atau kekuasaan.

Sulistiyani (2004) menjelaskan lebih rinci bahwa secara etimologis 
pemberdayaan berasal dari kata dasar "daya" yang berarti kekuatan atau kemampuan. Pemberdayaan dimaknai sebagai proses untuk memperoleh daya, kekuatan atau kemampuan, dan atau proses pemberian daya, kekuatan atau kemampuan dari pihak yang memiliki daya kepada pihak yang kurang atau belum berdaya. Berdasarkan beberapa pengertian pemberdayaan yang dikemukakan tersebut, maka dapat disimpulkan bahwa pada hakekatnya pemberdayaan adalah suatu proses dan upaya untuk memperoleh atau memberikan daya, kekuatan atau kemampuan kepada individu dan masyarakat lemah agar dapat mengidentifikasi, menganalisis, menetapkan kebutuhan dan potensi serta masalah yang dihadapi dan sekaligus memilih alternatif pemecahannya dengan mengoptimalkan sumberdaya dan potensi yang dimiliki secara mandiri.

\section{Tujuan dari Pemberdayaan} untuk meningkatkan kekuatan orangorang yang lemah (Ife, 1995), Pada dasarnya pemberdayaan dapat dimaknai sebagai segala usaha untuk membebaskan masyarakat miskin dari belenggu kemiskinan yang menghasilkan suatu situasi di mana kesempatan-kesempatan ekonomis tertutup bagi mereka, karena kemiskinan yang terjadi tidak bersifat alamiah semata, melainkan hasil berbagai macam faktor yang menyangkut kekuasaan dan kebijakan, maka upaya pemberdayaan juga harus melibatkan kedua faktor kekuasaan dan kebijakan dari perusahaan.

Keberdayaan bermakna sebagai keadaaan sudah berdaya. Sedangkan pemberdayaan berarti proses atau usaha untuk membuat sesuatu menjadi berdaya. Keberdayaan dalam konteks masyarakat adalah kemampuan individu yang bersenyawa dengan masyarakat dan membangun keberdayaan masyarakat yang bersangkutan (Sumaryadi, 2005). Masyarakat yang memiliki sehat fisik dan mental, terdidik dan kuat, tentunya memiliki keberdayaan masyarakat merupakan unsur dasar yang memungkinkan suatu masyarakat memiliki kemampuan bertahan dan dalam pengertian yang dinamis mengembangkan diri dan mencapai kemajuan.

Pemberdayaan masyarakat juga dapat diartikan sebagai upaya mengembangkan, memandirikan, menswadayakan, dan memperkuat posisi tawar masyarakat lapisan bawah terhadap kekuatan-kekuatan penekan di segala bidang dan sektor kehidupan melalui pengalihan pengambilan keputusan kepada masyarakat agar mereka terbiasa dan mampu bertanggungjawab terhadap segala sesuatu yang dipilihnya (Najiyati et al., 2005).

Berdasarkan kajian terhadap berbagai pustaka tentang konsep pemberdayaan pada hakekatnya merupakan upaya yang dilakukan terhadap individu atau komunitas lokal yang kurang mampu agar mereka memiliki kemampuan, kekuatan, pengaruh, kontrol, penguasaan dan akses yang lebih besar terhadap sumberdaya sehingga bisa memperbaiki dan meningkatkan kualitas kehidupannya secara mandiri. Kemampuan mengandung makna individu, atau komunitas lokal menjadi lebih berdaya, memiliki pengetahuan, 
mempunyai motivasi, melihat adanya peluang dan bisa memanfaatkannya serta mampu mengambil keputusan dan bertindak secara tepat sesuai dengan situasi yang dihadapi. Pemberdayaan menunjukkan dimensi proses dan dimensi hasil pada subyek yang diberdayakan. Dimensi proses dari pemberdayaan merupakan berbagai upaya yang dilakukan terhadap subyek yang diberdayakan. Dimensi hasil menunjukkan sejauhmana tingkat keberdayaan yang terjadi dari subyek tersebut.

\section{Pemberdayaan Masyarakat melalui Program Corporate Social Responsibility}

Diskursus mengenai CSR sampai saat ini tetap hangat dan menarik untuk diperbincangkan oleh perusahaan terutama yang bergerak dibidang minyak dan gas bumi. Meningkatnya kesadaraan perusahaan dalam melakukan dan menerapkan tanggungjawab sosial dilingkungan usahanya didorong oleh cepatnya arus globalisasi dan liberalisasi di berbagai sektor. Ini ditunjukkan dengan meningkatnya jumlah sektor usaha yang beroperasi dan melakukan kegiatan tanggungjawab sosial sebagai CSR kepada masyarakat sekitar sebagai bentuk kepedulian perusahaan. Terkait dengan CSR, menyatakan bahwa dunia bisnis, selama ini telah menjelma menjadi institusi yang paling berkuasa. Institusi yang dominan di masyarakat mana pun harus mengambil tanggungjawab sosial untuk kepentingan bersama. Untuk setiap keputusan yang dibuat, setiap tindakan yang diambil, haruslah dilihat dalam kerangka CSR tersebut. Penerapan CSR di kalangan perusahaan di Indonesia belakangan ini menunjukkan adanya perkembangan dan manfaat positif yang dapat dinikmati oleh masyarakat. Program ini diwujudkan melalui serangkaian kegiatan yang dilakukan perusahaan di berbagai bidang seperti: pendidikan, kesehatan, ekonomi, lingkungan dan bahkan sosial budaya yang dikemas dalam bentuk charity, philanthropy dan community development.

Menurut Ndara (1990), bahwa pemberdayaan masyarakat terbagi atas empat macam, yaitu:

1. Pemberdayaan politik, bertujuan meningkatkan bargaining position yang diperintah terhadap pemerintah, sehingga yang diperintah mendapatkan apa yang merupakan haknya dalam bentuk barang, jasa layanan, dan kepedulian tanpa merugikan orang lain.

2. Pemberdayaan ekonomi, dimaksud sebagai upaya untuk meningkatkan kemampuan yang diperintah sebagai consumer untuk berfungsi sebagai penanggung dampak negatif pertumbuhan, pembayar resiko salah urus, pemikul beban pembangunan, kambing hitam kegagalan program dan penderita kerusakan lingkungan.

3. Pemberdayaan sosial budaya, bertujuan meningkatkan kemampuan sumberdaya manusia melalui human investment, guna meningkatkan nilai manusia, penggunaan dan perlakuan seadilnya terhadap manusia.

4. Pemberdayaan lingkungan, dimaksudkan sebagai program 
perawatan dan pelestarian lingkungan, supaya yang diperintah dengan lingkungannya terdapat hubungan saling menguntungkan.

Program CSR yang berkelanjutan akan memberikan dampak positif dan manfaat yang lebih besar baik keberdayaan masyarakat di bidang politik, ekonomi, sosialbudaya dan lingkungan. Menurut Rahman (2009), isu kegiatan CSR sangat beragam, sementara fokus CSR di negara maju fokus kegiatan CSR lebih bervariasi, diantaranya isu hak azazi manusia, pemenuhan hak-hak buruh, penyelenggaraan bisnis yang bebas korupsi dan orientasi pada lingkungan tidak atau belum terlalu berkembang. Sementara fokus isu CSR di negara berkembang lebih pada bagaimana perusahaan dapat memberdayakan masyarakat untuk mandiri dan peningkatkan taraf hidup. Baik negara maju maupun negara berkembang memiliki kesamaan pemahaman bahwa fokus kegiatan CSR adalah kedermawaan sosial.

Menurut Rahman (2009), sejumlah isu yang dapat diangkat dalam CSR antara lain:

1. Isu lingkungan

Isu pemanasan global yang sedang marak diberitakan bahwa perubahan lingkungan dunia kian memprihatinkan. Organisasi bisnis merupakan salah satu penyumbang terjadinya global warning turut andil dalam masalah ini. Diharapkan melalui kegiatan CSR lebih peduli terhadap isu lingkungan.

2. Isu sosial
Aspek sosial dari kegiatan CSR selalu terkait dengan stakeholder perusahaan yaitu: pemerintah, organisasi bisnis lainnya, konsumen, karyawan, investor, rekan bisnis dan komunitas lokal. Stakeholder mengharapkan perusahaan bertindak penuh dan bertanggungjawab kepada masayarakat. Jika harapan dari stakeholder tidak terpenuhi dapat saja stakeholder melakukan tindakan yang dapat mengancam kesuksesan dari perusahaan dalam menjalankan operasi/bisnisnya. Sehingga perusahaan harus peduli terhadap isu sosial.

3. Isu ekonomi

Perekonomian masyarakat miskin yang tinggal di daerah sekitar perusahaan memberikan tanda bahwa masyarakat menjadi isu yang penting untuk diperhatikan oleh perusahaan. Melalui kegiatan CSR diharapkan akan meningkatkan perekonomian masyarakat sekitar, sehingga dirasakan manfaatnya oleh masyarakat.

\section{Metode Penelitian}

Penelitian ini dilakukan di Balongan Kabupaten Indramayu-Jawa Barat. Pemilihan lokasi penelitian ini disebabkan karena di Kabupaten Indramayu terdapat industri minyak dan gas bumi baik hulu maupun hilir. Pengelolaan minyak dan gas bumi tersebut dikelola oleh PT Pertamina melalui Daerah Operasi Hulu (DOH) Cirebon untuk ekploitasi dan eksplorasi, PT Pertamina Refinery Unit VI Balongan untuk pengelolaan dan Jakarta untuk pemasarannya. Khusus untuk Balongan 
bahan bakunya berasal dari luar Kabupaten Indramayu.

Pendekatan penelitian ini adalah pendekatan kualitatif, yang bersifat deskriptif. Unit analisis dalam penelitian ini adalah masyarakat yang tinggal di wilayah ring satu kilang Balongan yang menerima manfaat dari program CSR yang dilaksanakan oleh PT Pertamina Refinery Unit VI Balongan. Obyek penelitian ini adalah pelaksanaan program CSR. Penelitian dilakukan dengan mengambil lokasi di Balongan, Kabupaten Indramayu karena mengingat di wilayah tersebut PT Pertamina Refinery Unit VI Balongan beroperasi. Sebagai sumber penelitian adalah PT Pertamina Refinery Unit VI, Jalan Raya Balongan $\mathrm{Km}$ sembilan Kabupaten Indramayu-Jawa Barat.

Teknik pengumpulan data secara primer yang digunakan dalam penelitian ini berupa:

a. Wawancara, yaitu percakapan antara periset sebagai seseorang yang berharap mendapat informasi dengan informan sebagai seseorang yang diasumsikan mempunyai informasi penting tentang suatu obyek. Wawancara mendalam termasuk wawancara semi terstruktur.

b. Diskusi Kelompok, merupakan metode untuk menggali data kualitatif dari sekelompok orang yang bertanya tentang sikap dan pendapat mereka terhadap suatu isu atau tema terkait dengan penelitian. Mengumpulkan beberapa perwakilan dari masyarakat Balongan, Majakerta, Sukaurip dan Karangsong untuk diajak berdiskusi terhadap manfaat yang dirasakan masyarakat akan adanya program CSR yang dilakukan PT Pertamina.

c. Observasi, Deskripsi lapangan dari aktivitas, perilaku, tindakan, percakapan, interaksi antar personal, proses dalam organisasi atau masyarakat, atau aspek lain dari pengalaman manusia yang dapat diamati. Data terdiri dari catatan lapangan: deskripsi rinci, termasuk konteks pengamatan (Patton, 2002).

Teknik pengumpulan data secara sekunder diperoleh dari:

a. Company Profile PT Pertamina.

b. Company Profile kegiatan TSP PT Pertamina (Persero) Refinery Unit VI Balongan.

c. Instansi Pemerintahan Daerah Indramayu, Jawa Barat.

d. Buku-buku literatur yang digunakan, jurnal, majalah maupun data lain yang didapat dari sumber sekunder.

\section{Hasil dan Pembahasan}

Program CSR yang dilakukan Pertamina merupakan komunikasi untuk eksternal perusahaan. Program CSR merupakan refleksi nilai dan budaya perusahaan yang terintegrasi, dengan strategi bisnis perusahaan masa kini dan mendatang, yang memberikan manfaat bagi Pertamina, shareholder dan stakeholders. Perusahaan merasa bahwa dalam beroperasinya kilang Balongan memberikan dampak negatif bagi masyarakat yang tinggal di sekitar kilang Balongan seperti berbagai polusi udara, air dan tanah yang mengganggu 
lingkungan hidup masyarakat. Berakat dari maalah tersebut maka Pertamina mulai memikirkan agar masyarakat sekitar tidak hanya menerima dampak negatif saja namun juga dampak positif dari pengelolaan minyak dan gas bumi baik sektor hulu maupun sektor hilir. Berdasarkan hasil wawancara yang dilakukan dengan salah seorang tokoh informal, mengatakan bahwa dampak positif dalam pengelolaan minyak dan gas bumi antara lain adalah:

"Berkembangnya pemukiman
masyarakat di sekitar kilang
Balongan, terciptanya lapangan
pekerjaan dan usaha baru bagi
masyarakat sehingga mengurangi
angka pengangguran masyarakat,
masuknya teknologi-teknologi
moderen bagi masyarakat,
terciptanya sistem nilai dan budaya
masyarakat yang moderen,
tersedianya sarana dan prasarana
bagi masyarakat dan
berkembangnya pasar dan
perekonomian masyarakat yang
bertujuan untuk meningkatkan taraf
hidup masyarakat."

Pertamina dalam melakukan berbagai program CSR dari berbagai bentuk dan sifat kegiatan, tujuannya adalah agar dapat menjangkau seluruh aspek kehidupan masyarakat. Dalam melaksanakan berbagai kegiatan tersebut perusahaan berusaha menggali informasi tentang kebutuhan masyarakat sekitar yang paling utama yang memang diperlukan oleh masyarakat. Informasi didapatkan perusahaan melalui pendamping program dari berbagai kebutuhan yang diperoleh tersebut perusahaan memilih dan mengadakan berbagai kegiatan tersebut antara lain:
1. Kegiatan yang bersifat charity atau perbuatan amal. Bentuk kegiatan ini hanya memberikan dampak terhadap masyarakat hanya untuk menyelesaikan masalah sesaat, hampir tidak ada peningkatan kesejahteraan bagi masyarakat. Kegiatan ini dilakukan untuk memenuhi keinginan dan kebutuhan masyarakat setempat berdasarkan survei kebutuhan masyarakat. Kegiatan ini dilakukan dengan biaya yang lebih murah namun memiliki dampak yang sangat baik dalam membentuk persepsi dan citra perusahaan di mata stakeholders.

2. Kegiatan yang bersifat community development. Kegiatan ini dilakukan salah satunya bertujuan untuk pemberdayaan masyarakat. Dampak yang dirasakan masyarakat adalah jangka panjang. Tujuan Pertamina melakukan kegiatan yang bersifat community development adalah untuk memberdayakan masyarakat Balongan di bidang ekonomi, sosial dan pengelolaan lingkungan hidup. Kegiatan community development ini dilakukan secara berkelanjutan sehingga dapat membentuk masyarakat yang berdaya dan mandiri.

Program CSR yang dilakukan oleh Pertamina untuk masyarakat sekitar perusahaan dengan melihat hasil laporan tahunan mengenai program yang dilaksanakan antara lain:

1. Di bidang pendidikan: memberikan beasiswa kepada masyarakat yang berprestasi, merenovasi bangunan sekolah, membangun ruang perpustakaan, merenovasi lapangan upacara untuk sekolah dasar negeri 
dan swasta, membagi-bagikan komputer untuk beberapa sekolah yang terdapat di sekitar wilayah kilang Balongan dan membagibagikan alat tulis kepada masyarakat.

2. Di bidang sosial: membagi-bagikan sembako, susu cair, sunatan massal, melaksanakan donor darah secara rutin, memberikan santunan kepada orangtua jompo dan anak yatim, membangun bak penampungan air bersih di lokasi tanah penyangga, memasang instalasi listrik untuk masyarakat Majakerta, dan memberikan bantuan kepada masyarakat yang terkena bencana alam.

3. Di bidang kesehatan: memberikan bantuan alat kesehatan di puskesmas Kecamatan Balongan, Kecamatan Indramayu, Kecamatan Juntinyuat dan Kecamatan Compreng, memberikan bantuan pengobatan massal secara rutin yakni sekali dalam sebulan dan pemberian air bersih untuk wilayah blok Kesambi Balongan diprioritaskan kegiatan di bidang kesehatan di wilayah ini, karena wilayah ini merupakan wilayah yang paling dekat dengan kilang Balongan. Kegiatan lainnya adalah memberikan makanan dan suplemen untuk peningkatan gizi balita, bantuan paket makanan bergizi kepada masyarakat yang kurang mampu yang tinggal di wilayah ring satu kilang Balongan.

4. Di bidang keagamaan: melakukan renovasi beberapa masjid yang terdapat di lingkungan kilang Balongan, membagi-bagikan Alquran, buku keagamaan di masjidmasjid yang berada di sekitar kilang
Balongan, memberikan bantuan hewan qurban kepada Mustahik dalam rangka peringatan hari raya Idul Adha, mengadakan acara untuk memperingati Isra Mi'raj.

5. Di bidang olah raga: membangun sarana olah raga untuk masyarakat seperti lapangan volli, lapangan sepak bola dan lapangan bulu tangkis, pembuatan fieldroom di stadion Dharma Ayu Indramayu.

6. Di bidang ekonomi: pengelolaan tanah penyangga yang dapat dinikmati oleh masyarakat seluas 250 hektar persawahan yang dapat dipergunakan oleh masyarakat, memberikan pemodalan untuk modal kerja masyarakat, melaksanakan pembinaan dan pelatihan untuk para petani, peternak dan nelayan.

7. Di bidang pengelolaan lingkungan hidup: melaksanakan penanaman pohon dan kegiatan memelihara pohon yang sudah ada, pembangunan sarana dan sarana, membangun irigasi, membangun drainase, membangun tempat pembuangan sampah, membangun got, membangun taman kota, membantu pelaksanaan pembangunan WC umum (MCK) di Desa Majakerta dan melaksanakan kegiatan pelatihan dan pembinaan di bidang lingkungan hidup.

Dari program-program diatas didasarkan pada kebutuhan masyarakat diseluruh bidang kehidupan manusia. Kegiatan yang dilakukan tersebut merupakan hasil pendataan yang dilakukan oleh pendamping program CSR kepada masyarakat sekitar 
perusahaan. Dimana dari masingmasing kegiatan yang terkumpul dikelompokkan berdasarkan bidang kehidupan manusia dan dimana kegiatan yang menjadi prioritas masyarakat sekitar perusahaan yang akan dilaksanakan oleh perusahaan. Sehingga kegiatan yang dilakukan memiliki kebermanfaatan bagi penerima program CSR tersebut. Kegiatan tersebut tidak terfokus hanya pada satu desa saja namun tersebar berdasarkan kebutuhan dari masyarakatnya dan dilakukan secara rutin dan berkesinambungan oleh Pertamina terutama kpada kegiatan yang sifatnya pelatihan dan pemberdayaan masyarakat.

Pertamina memfokuskan pada kegiatan di bidang pengelolaan lingkungan hidup untuk menjaga dan melestarikan lingkungan dan ikut menyukseskan gerakan penanaman sejuta pohon tahun 2009. Pertamina melaksanakan program one man one tree dengan menanam 2.010 bibit pohon. Adapun jenis bibit pohon yang disediakan antara lain: sebanyak 715 bibit pohon mahoni, sebanyak 356 bibit pohon palem, sebanyak 104 bibit pohon trembesi, sebanyak 835 bibit pohon glodokan tiang. Semua bibit pohon ini ditanam di area kilang, laydown area, dan area pertanaman Pertamina Balongan. Sebagai wujud kepedulian Pertamina terhadap lingkungan, Pertamina secara simbolis juga menyerahkan bantuan sebanyak 50.000 bibit tanaman penghijauan berupa mangrove untuk ditanam di wilayah Kabupaten Indramayu.

Berdasarkan hasil laporan tahunan Pertamina pada tahun 2011 melakukan kegiatan CSR yang bersifat community development, di antaranya melakukan kegiatan pelatihan untuk para nelayan di Kabupaten Indramayu bekerjasama dengan Dinas Kelautan dan Perikanan dengan Dinas Lingkungan Hidup. Hal ini dikarenakan sebahagian besar mata pencaharian masyarakat adalah nelayan. Kegiatan ini berupa pelatihan pembuatan serta bantuan alat tangkap ikan, materi terkait dengan Program Peningkatan Kualitas Lingkungan (PPKL), kegiatan ini merupakan kegiatan lanjutan dari program yang telah digulirkan sebelumnya yang sejalan dan mendukung Keppres Peningkatan Kehidupan Nelayan (PKN). Terkait dengan strategi "revolusi biru" dari Menteri Kelautan dan Perikanan dalam peningkatan produksi hasil laut bagi nelayan, baik untuk kebutuhan dalam negeri maupun untuk diekspor. Pelatihan ini dilaksanakan dengan tujuan membantu masyarakat untuk menjadi lebih mandiri dan berdaya di bidang ekonomi.

Dari hasil wawancara yang dilakukan dengan salah seorang staf Hupmas Pertamina Balongan, mengatakan bahwa:

"Kegiatan pada tahun 2011 ini merupakan kelanjutan dari kegiatan 2010 yang belum tuntas dilakukan, di antaranya membangun waterbreak, memasang aliran listrik untuk masyarakat yang rumahnya belum menggunakan listrik, melakukan penanaman pohon dan pemeliharaan pohon yang telah ditanam pada tahun kemarin, merenovasi sarana dan prasarana yang sudah tidak layak pakai, membina hubungan baik dengan wartawan media cetak dan media 
elektronik, memberikan santunan untuk orangtua jompo dan anak yatim, pembagian susu cair dan sembako, memberikan hewan qurban, untuk kegiatan di bidang ekonomi masih seperti tahun kemarin seperti mengelola tanah penyangga, memberikan bantuan modal bagi masyarakat, melaksanakan pelatihan dan pembinaan."

Pertamina berinisiatif untuk melaksanakan kegiatan merupakan keharusan bagi perusahaan yang bergerak di bidang minyak dan gas bumi untuk melakukan kegiatan, dimana konsep pertama berorientasi pada pemberdayaan masyarakat secara berkesinambungan; yang kedua relation development merupakan kegiatan yang lebih bersifat charity dan donasi publik. Termasuk dalam kategori ini adalah pembinaan hubungan segitiga yang baik dan harmonis antara perusahaan, pendamping program kegiatan dan masyarakat lokal. Dimana hubungan segitiga ini jika tercipta hubungan yang baik dan harmonis akan mampu menciptakan masyarakat yang berdaya.

Penerapan kegiatan CSR Pertamina merupakan refleksi nilai dan budaya perusahaan yang terintegrasi dengan strategi bisnis perusahaan masa kini dan mendatang, yang memberikan manfaat bagi Pertamina, shareholder dan stakeholder. Oleh karena itu kesuksesan perusahaan tidak hanya ditentukan dari keberhasilan menjalankan bisnis semata, tetapi juga didukung kemampuan dalam menyukseskan program pemberdayaan masyarakat dan lingkungan hidup melalui CSR. Pertamina dalam penerapan CSR diprioritaskan untuk membantu masyarakat dan pemerintah dalam memecahkan permasalahan sosial di sekitar Perusahaan. Pelaksanaan kegiatan dikendalikan sepenuhnya oleh perusahaan, dan bekerjasama dengan pemerintah dan lembaga lainnya. Melalui kegiatan ini akan memberikan nilai tambah bagi Pertamina untuk semakin mendekatkan produk dan brand kepada masyarakat. Pertamina menganggap CSR sebagai wujud good corporate governance, yaitu sistem pemerintahan yang baik dan peduli terhadap lingkungan.

$\begin{array}{ccr}\text { Perkembangan CSR yang } \\ \text { dilakukan berupaya } & \text { untuk }\end{array}$ memberdayakan masyarakat. Praktik CSR sebagai wujud implementasi program dari community relations, jika ditujukan pada stakeholder yang tepat dan dilakukan secara tepat pula akan dapat menciptakan sebuah kondisi lingkungan yang kondusif bagi perusahaan, sehingga perusahaan akan dapat menjalankan aktivitas bisnisnya dengan baik tanpa adanya hambatanhambatan yang dapat muncul dari lingkungan sekitar (Thamrin et al., 2010).

Visi dari kegiatan CSR Pertamina Balongan adalah menciptakan dan memelihara hubungan harmonis dengan lingkungan sekitar serta bekerjasama dengan pemerintah untuk memberikan manfaat yang besar bagi masyarakat.

Misi kegiatan CSR Pertamina Balongan: (1) Mengimplementasikan komitmen perusahaan terhadap CSR untuk memberikan nilai tambah bagi stakeholders dalam upaya mendukung kemajuan perusahaan, (2) Mewujudkan kepedulian sosial Pertamina Balongan dan kontribusi perusahaan terhadap 
pengembangan masyarakat yang berkelanjutan.

Tujuan dari kegiatan CSR Pertamina Balongan: (1) Membangun hubungan yang harmonis dan menciptakan kondisi yang kondusif untuk mendukung pertumbuhan perusahaan, (2) Memberikan kontribusi dalam memecahkan permasalahan sosial, (3) Meningkatkan nilai dan budaya perusahaan yang terintegrasi dengan strategi bisnis perusahaan, dan (4) Bagian dari upaya membangun citra dan reputasi perusahaan.

Komunikasi organisasi yang dilaksanakan oleh Hupmas Pertamina didasarkan pada Kepmen No Kep236/MBU/2003 membawa babak baru bagi visi, misi dan kebijakan sosial Pertamina. Melalui keputusan tersebut, Pertamina yang telah menyalurkan dana Pembinaan Usaha Kecil dan Koperasi (PUKK) sejak tahun 1990, membentuk unit Program Kemitraan dan Bina Lingkungan (PKBL) untuk menggantikan peran PUKK. Dengan menggunakan dana bagian pemerintah atas penyisihan laba bersih Pertamina untuk PKBL. Dengan demikan fungsi sosial dari Pertamina bertambah lagi dengan pembentukkan unit khusus ini, baik di tingkat korporat maupun daerah operasi/unit.

Program CSR merupakan kegiatan yang wajib dilakukan oleh perusahaan sesuai dengan UndangUndang Perseroan Terbatas UU-PT Pasal 74. Esensi UU-PT ini menegaskan bahwa dunia usaha tidak lagi hanya memperhatikan aspek financial usaha semata (single bottom line), melainkan juga harus menggunakan baik aspek keuangan, sosial dan lingkungan hidup (triple bottom line). Sinergi antara ketiga elemen tersebut merupakan kunci keberhasilan dari konsep pembangunan berkelanjutan. Kegiatan TSP merupakan bagian yang tidak terpisahkan dari kegiatan community development. Namun pada prakteknya sebahagian dari kegiatan TSP dilakukan sekedar pada perbuatan amal (charity) perusahaan saja dan tidak menyentuh kepada pemberdayaan masyarakat melainkan akan berdampak pada perusahaan itu sendiri.

Jenis CSR yang dilaksanakan oleh Pertamina kepada masyarakat disesuaikan menurut wilayah ring tempat tinggal masyarakat. Pertamina selama ini terus memperbaiki kekurangan-kekurangan dari setiap kegiatan yang dilaksanakan sehingga kegiatan berikutnya dapat berjalan semakin baik dan menyentuh pada kehidupan sosial yang dapat memberdayakan masyarakat. Diharapkan melalui kegiatan CSR merupakan alat untuk mendorong perubahan masyarakat menjadi lebih berdaya, mandiri dan produktif yang tidak menggantungkan kehidupannya pada pihak luar dan perusahaan.

Program CSR yang dilakukan Pertamina harus memiliki kualitas program yang baik. Dikatakan kegiatan tersebut memiliki kualitas yang baik jika bermanfaat bagi si penerima. Pertamina dalam melaksanakan program CSR menggunakan dua saluran komunikasi. Saluran komunikasi yang digunakan melalui saluran komunikasi interpersonal dan saluran komunikasi media massa, sehingga antara kualitas program kegiatan dan pengkomunikasian program kegiatan CSR dapat berjalan dengan baik dan dalam kategori baik. 
Pemilihan media cetak maupun elektronik yang tepat akan membantu masyarakat untuk memperoleh informasi yang dibutuhkan.

Kegiatan CSR yang dilakukan sangat beragam, kegiatan di bidang ekonomi bertujuan untuk memberikan nilai tambah dan memberdayakan masyarakat sekitar Pertamina, memberikan peluang kepada masyarakat untuk menambah perekonomian keluarga dan mendukung pertumbuhan perekonomian masyarakat dan usaha kecil serta menengah di Kabupaten Indramayu. Kegiatan di bidang ekonomi yang dilaksanakan antara lain: pengelolaan tanah penyangga, melalui program kegiatan ini diharapkan masyarakat dapat merasakan hasilnya. Taraf hidup dan perekonomian mereka meningkat dan relatif lebih stabil. Mereka juga dapat menyejahterakan keluarga mereka dan meningkatkan kualitas pendidikan anak-anaknya. Memberikan pemodalan di bidang usaha perikanan, pertanian, perternakan, perdagangan, pengrajin, perbengkelan dan jasa. Melakukan pembinaan di setiap bidang usaha yang telah dibekali dengan keahlian dan pengetahuan, antara lain di bidang pertanian, perikanan, peternakan, perdagangan, pengrajin, perbengkelan dan jasa. Hasil dari program pembinaan diharapkan masyarakat menjadi mampu untuk bersaing dengan pihak luar dari masing-masing bidang usaha.

Kegiatan di bidang sosial, didasari oleh pemikiran bahwa sebagai perusahaan yang berada di tengah masyarakat, Pertamina Balongan mempunyai tanggungjawab sosial dalam menciptakan masyarakat yang lebih baik serta membantu meringankan beban masyarakat. Adapun program kegiatan yang sudah dan sedang dilaksanakan oleh Pertamina Balongan antara lain: melakukan pembagian sembako, pemberian santunan kepada orang tua jompo dan anak yatim, memberikan tunjangan bagi guru dan staf pengajar, melaksanakan donor darah, membagikan susu cair secara rutin setiap dua bulan sekali, melaksanakan pengobatan massal secara rutin setiap sebulan sekali, bantuan paket makanan bergizi bagi masyarakat yang kurang mampu, menciptakan lapangan pekerjaan, membuat perpustakaan keliling, seremonial dan sosialisasi. Sebagian besar dari program kegiatan CSR di bidang sosial yang dilakukan oleh Pertamina merupakan kegiatan yang bersifat charity atau perbuatan amal, dampak yang dirasakan oleh masyarakat bersifat jangka pendek.

Kegiatan di bidang pengelolaan lingkungan hidup yang dilaksanakan oleh Pertamina didasari oleh pemikiran bahwa operasional kilang Balongan memberikan dampak negatif bagi masyarakat sekitar. Diharapkan dengan kegiatan CSR yang dilaksanakan dapat mengurangi resiko atau dampak negatif dari operasional kilang Balongan. Kegiatan di bidang pengelolaan lingkungan hidup antara lain pengembangan sarana umum, membangun sarana pengelolaan limbah beracun dan limbah organik, sarana penampungan sampah, penanaman pohon baik di darat maupun di lingkungan air, penampungan air, pembangunan sarana drainase, pengadaan pompa air, membangun wc umum (MCK), dan memasang instalasi 
listrik bagi yang belum memiliki. Di bidang pengelolaan lingkungan hidup Pertamina bersama dengan masyarakat sekitar untuk menciptakan lingkungan yang bersih dan terbebaskan dari polusi air, udara dan tanah.

Kegiatan yang dilakukan oleh Pertamina dalam melakukan perubahan, mendorong dan mempertinggi motivasi serta alat untuk mencapai tujuan yaitu pemberdayaan masyarakat. Pertamina memiliki maksud dan tujuannya, seperti yang diungkapkan oleh salah seorang staf Hupmas Pertamina Balongan bahwa:

“..kegiatan ini dilakukan memiliki dua tujuan. Tujuan yang pertama adalah untuk memberdayakan masyarakat dalam segala bidang kehidupan, sedangkan tujuan kedua adalah untuk memperoleh persepsi positif dari stakeholder. Persepsi positif dari masyarakat akan menciptakan citra positif bagi perusahaan. Persepsi positif akan menciptakan dukungan masyarakat terhadap perusahaan dan mendukung berjalannya operasional perusahaan."

Citra positif perusahaan sangat penting, karena citra perusahaan merupakan keseluruhan kesan yang terbentuk dibenak masyarakat tentang perusahaan. Citra dapat berhubungan dengan nama perusahaan, produk yang dihasilkan, kegiatan yang dilakukan, kualitas komunikasi yang dilakukan oleh setiap karyawan dengan stakeholder perusahaan. Citra perusahaan dapat dipersepsikan sebagai gambaran mental secara selektif tentang karakteristik perusahaan yang nantinya akan membentuk citra perusahaan dibenak masyarakat. Citra merupakan bagaimana pihak lain memandang perusahaan. Setiap perusahaan dapat memiliki lebih dari satu citra tergantung dari kondisi interaksi yang dilakukan oleh perusahaan dengan stakeholder perusahaan.

Pengertian citra itu sangat abstrak dan tidak dapat diukur secara matematis, tetapi wujud citra dapat dirasakan dari hasil persepsi baik atau buruk seperti penerimaan dan tanggapan positif atau negatif yang berasal dari stakeholders. Citra perusahaan berkaitan dengan sosok perusahaan sebagai tujuan utamanya, bagaimana citra perusahaan yang positif lebih dikenal dan diterima oleh publiknya mungkin tentang sejarahnya, kualitas pelayanan prima, keberhasilan dalam bidang marketing dan berkaitan dengan kegiatan tanggungjawab sosial yang dilakukan (Ardianto \& Soemirat, 2007).

Masyarakat memiliki citra yang positif terhadap Pertamina terlihat dari tingkat pengetahuan mereka terhadap perusahaan dan berbagai atribut yang mencerminkan Pertamina. Selain itu masyarakat selalu mengetahui bahwa berbagai kemajuan yang dirasakan masyarakat merupakan bentuk perhatian perusahaan terhadap masyarakatnya melalui berbagai program dan kegiatan CSR yang rutin dan berkesinambungan yang dilakukan oleh Pertamina untuk masyarakat sekitar. Bentuk lain terlihat dari masyarakat dapat menerima Pertamina beroperasi ditenggah-tenggah kehidupan masyarakat dikarenakan masyarakat merasakan manfaat dan dampak positif yang mereka rasakan dari berbagai kegiatan tanggungjawab 
sosial yang sudah dilakukan oleh Pertamina.

Program CSR yang dilakukan oleh Pertamina merupakan investasi bagi pertumbuhan dan keberlanjutan perusahaan dan bukan lagi dilihat sebagai sarana biaya melainkan sarana untuk meraih keuntungan dan menciptakan persepsi, citra positif masyarakat dan mengurangi resiko perusahaan dari gejolak yang berasal dari masyarakat sekitar. Hal ini diperkuat dengan pendapat Harmoni dan Andriyani (2008), Sebagian perusahaan menganggap bahwa mengomunikasikan kegiatan atau program CSR sama pentingnya dengan kegiatan CSR itu sendiri. Dengan mengomunikasikan CSR-nya, makin banyak masyarakat yang mengetahui investasi sosial perusahaan sehingga tingkat resiko perusahaan menghadapi gejolak sosial akan menurun. Jadi, melaporkan CSR kepada khalayak akan meningkatkan nilai social hedging perusahaan.

Program CSR merupakan komitmen perusahaan untuk mendukung terciptanya pembangunan berkelanjutan. Di sisi lain juga masyarakat membutuhkan kepedulian perusahaan untuk melaksanakan kegiatan sosial. Program kegiatan CSR salah satu bentuk komunikasi organisasi dalam upaya membangun citra positif dan reputasi perusahaan yang pada akhirnya akan meningkatkan kepercayaan dari para masyarakat. Program CSR memang tidak mendapatkan profit, yang diharapkan dari kegiatan ini adalah benefit berupa persepsi dan citra perusahaan dari masyarakat. Menyadari pentingnya kegiatan ini perusahaan diharapkan fokus pada membina hubungan dengan masyarakat. Hal ini merupakan fenomena positif di lingkungan bisnis, telah menunjukkan meningkatnya kesadaran bahwa perusahaan tidak semata-mata mengejar keuntungan tetapi juga harus menjaga aspek sosial dan lingkungan (Harijono, 2007).

Kegiatan yang sedang gencar dilakukan oleh Pertamina yang terkait dengan menjaga aspek lingkungan hidup adalah pengelolahan sampah yang dilakukan oleh Pertamina bekerjasama dengan pemerintah daerah. Dimana sampah dai kebutuhan hidup masyarakat yang sangat banyak dan jika tidak dikelolah dengan baik akan mengakibatkan berbagai penyakit yang dapat menyerang kesehatan masyarakat. Program ini disebut sebagai program "Bank Sampah", dimana biasanya masyarakat membuang sampah disembarang tempat dan memudhkan tertular berbagai penyakit sekarang sudah ada bak sampah yang disediakan sehingga masyarakat tidak membuang sampah disembarang tempat lagi. Setelah itu masyarakat dapat memilih sampah yang isa dijual kembali dan sampah yang harus dibuang ketempat pembuangan akhir. Seperti yang diungkapkan oleh salah seorang masyarakat Balongan mengatakan bahwa:

"dengan adanya bank sampah kami diberikan pelatihan untuk dapat menambah pemasukan bagi kami warganya karena dapat memilih kembali barang-barang yang dapat kami jual kembali dan uang tersebut dapat kami gunakan untuk menambah kebutuhan hidup keluarga kami selain itu juga lingkungan tempat kami tinggal 
menjadi terbebaskan dari sampahsampah yang berserakan".

Program-program CSR yang dilakukan jika disesuaikan dengan keinginan dan kebutuhan masyarakat melalui survei terhadap kebutuhan masyarakat (need assessment) lokal oleh pendamping program kegiatan, yang bertujuan untuk membentuk suatu persepsi maupun citra yang diharapkan akan tercapai terlihat dari berbagai kegiatanyang telah dilakukan selama ini. Menurut Jefkins (2003) citra yang diharapkan (wish image) merupakan suatu citra yang diharapkan dan diinginkan oleh pihak manajemen, sedangkan menurut Ardianto dan Soemirat (2004) menjelaskan efek kognitif dari komunikasi sangat mempengaruhi proses pembentukkan citra seseorang. Persepsi dan citra terbentuk berdasarkan pengetahuan dan informasi-informasi yang diterima seseorang. Komunikasi tidak secara langsung menimbulkan perilaku tertentu, tetapi cenderung mempengaruhi cara kita mengorganisasikan citra tentang lingkungan.

Idealnya kegiatan yang dilakukan berdasarkan dari survei kebutuhan masyarakat dan mampu memberikan manfaat bagi perusahaan maupun masyarakat, sehingga akan menumbuhkan tingkat partisipasi masyarakat dalam tahap merencanakan, melaksanakan, memanfaatkan dan mengevaluasi kegiatan. Masyarakat yang berpartisipasi secara aktif dan mendapatkan manfaat dari kegiatan akan memiliki persepsi dan citra yang positif terhadap perusahaan maupun terhadap kegiatan CSR. Guna memantau keberhasilan program CSR
Pertamina dalam pemberdayaan masyarakat di Kecamatan Balongan Kabupaten Indramayu, Fungsi CSR Pertamina telah beerapa kali melakukan Monitoring dan Evaluasi (Monev), yang paling terakir melakukan Monev bersama LPPM Institut Pertanian Bogor (IPB) di tiga desa, yakni Desa Balongan, Desa Majakerta dan Desa Karangsong.

Menurut salah satu staff Hupmas membenarkan bahwa kegiatan CSR yang telah dilakukan akan selalu dievaluasi untuk melihat keberhasilan program tersebut. Monev yang pernah dilakukan oleh LPPM IPB, Ia mengatakan bahwa:

"Kegiatan Monev ini dilaksanakan selama 2 hari, pada 10 - 11 Februari 2015 yang diisi dengan sharing session, success story dan kunjungan langsung ke lapangan bersama kelompok masyarakat binaan Pertamina yang berlangsung di kantor desa di setiap desa. Kegiatan ini sebagai sarana untuk mengetahui kendala yang dihadapi masyarakat dalam menjalankan program CSR Pertamina.

Program CSR yang sifatnya pemberdayaan masyarakat yang sudah dijalankan diantaranya: melakukan budidaya entok, pembibitan dan budidaya ikan lele dan ikan mas, penetasan telur itik, pengolahan bakery and snack, pengolahan terasi, pengolahan bandeng tanpa duri, pengolahan pilus dan keripik dan perikanan tangkap. Hal ini dilakukan merupakan salah satu bentuk program CSR Pertamina yang memberikan manfaat jangka panjang bagi masyarakatnya. Tujuan dari kegiatan ini 
adalah memberdayakan masyarakat sekitar sehingga tidak hanya bergantung hidup dari perusahaan dengan mengharapkan charity perusahaan yang sifatnya hanya membuta ketergantungan saja namun juga dapat menambahkan penghasilan untuk keluarganya dari kegiatan pemberdayaan oleh Pertamina.

Tujuan secara umum dari berbagai program dan kegiatan CSR yang dilakukan oleh PT Pertamina secara rutin dan berkesinambungan dengan berbagai bidang kehidupan masyarakat adalah sebagai bentuk kepedulian perusahaan terhadap masyarakat Indonesia secara umum dan masyarakat sekitar perusahaan secara khusus. Selain itu juga untuk membantu berbagai program pemerintah dalam memperbaiki Indeks Pembangunan Manusia Indonesia yang memang dianggap masih belum baik, dengan adanya berbagai kegiatan tersebut sebagai bentuk perhatian dari Pertamina diharapkan Indeks Pembangunan Manusia Indonesia menjadi lebih baik.

\section{Kesimpulan}

Program CSR yang dilakukan oleh Pertamina terdiri atas dua yaitu kegiatan yang bersifat charity yang tujuannya adalah untuk jangka pendek bagi penerima manfaat. Kegiatan ini berguna untuk menciptakan image positif masyarakat terhadap perusahaan. Kegiatan yang kedua bersifat pemberdayaan masyarakat yang tujuannya adalah untuk jangka panjang bagi penerima manfaat dari kegiatan tersebut. Namun kegiatan ini dapat menciptakan masyarakat menjadi lebih berdaya dan tidak bergantung hidup pada perusahaan. Kegiatan ini dilakukan untuk menambah penghasilan masyarakat sekitar perusahaan, sehingga dengan adanya perusahaan disekitar lingkungan hidup masyarakat tidak hanya memberikan dampak negative namun juga memberikan manfaat bagi masyarakat.

\section{Saran}

Diharapkan program CSR yang bersifat charity, community development dan pemberdayaan masyarakat secara rutin tetap dilakukan oleh Pertamina dengan melakukan survey langsung ke masyarakat sehingga kegiatan yang dilakukan memang sesuai dengan kebutuhan masyarakat setempat. Jika kegiatan yang dilakukan sesuai dengan kebutuhan, masyarakat akan merasakan manfaat dari kegiatan tersebut.

\section{Daftar Rujukan}

Ardianto E, Soemirat S. 2007. Dasar-dasar public relations. Cetakan Ketiga. Bandung: Remaja Rosdakarya.

Carr E, Kristy HJ, Greg M, Sara M. 2004. Corporate social responsibility: A Study of Four Successful Vermont Companies, Vermont.

Djalil S. 2003. Kontek teoritis dan praktis Corporate social responsibility, Jurnal Reformasi Ekonomi. Vol.4. No.1: 4-11. 
Harmoni A, Andriyani A. 2008. Pengungkapan CSR pada official Website Perusahaan. Proceeding Seminar Ilmiah Nasional komputer dan sistem Intelijen (KOMMIT). Depok: Universitas Gunadarma.

Harijono T. 2007. CSR jangan dipandang sebagai derma. Jakarta: Kompas.

Ife J. 1995. Community development: creating community alternatives - vision, analysis and practice. Australia: Longman Australia Pty.LTD.

Iryani E. 2009. Komitmen stakeholders perusahaan terhadap kinerja sosial dan kinerja keuangan, [tesis]. Semarang : Universitas Diponegoro.

Iriantara Y. 2004. Community relations, konsep dan aplikasinya. Bandung: Simbiosa Rekatama Media.

Jefkins F. 2003. Public relations. Edisi Kelima. Jakarta: Erlangga.

Machiavelli DG. 2011. Pengaruh kinerja lingkungan dan pengungkapan informasi lingkungan terhadap kinerja ekonomi perusahaan manufaktur yang terdaftar di bursa efek Indonesia. http://garryaditya.blogspot.com/2011/01/jurnalcsr.html/ [diakses 23 Juni 2011].

Najiyati S, Asmana A, Suryadiputra IN. 2005. Pemberdayaan masyarakat di lahan gambut. Proyek Climate Change, Forests and Peatlands in Indonesia. Wetlands International- Indonesia Programme dan Wildlife Habitat Canada. Bogor.

Ndara T. 1990. Pembangunan masyarakat mempersiapkan masyarakat tinggal landas. Jakarta: Rineke Cipta.

Nursahid F. 2006. Praktik kedermawanan sosial BUMN: Analisis terhadap model kedermawanan PT. Krakatau Steel, PT. Pertamina dan PT. Telekomunikasi Indonesia, Jurnal Galang Vol 1 No 2: 5-10

Patton MQ. 2002. Qualitative research and evaluation methods. $3^{\text {rd }}$ Ed. London: Sage Publication.

Petkoski D, Twose N. 2003. Public policy for corporate social responsibility. Jointly sponsored by the World bank Institute, the private sector development vice presidency of the world bank, and the international finance corporation. http://info.worldbank.org/July [diakses 10 Desember 2010].

Rahman R. 2009. Corporate social responsibility: Antara teori dan kenyataan. Yogyakarta: Med Press.

Sulistiyani AT. 2004. Kemitraan dan model-model pemberdayaan. Yogyakarta: Gaya Media.

Sumaryadi IN. 2005. Perencanaan pembangunan daerah otonomi dan pemberdayaan masyarakat. Jakarta: Citra Utama. 
74 | ILONA V. OISINA SITUMEANG

Susanto AB. 2007. CSR dalam Perspektif Ganda. Jurnal CSR Indonesia Newsletter. Vol 1 No 37: 11-19.

Thamrin H, Syafganti I, Rangkuti B. 2010. Implementasi Corporate Social Responsibility Berbasis Modal Sosial di Sumatra Utara. Journal of Strategic Communication Vol 1 No 1: 76-89.

Wibisono Y. 2007. Membedah konsep dan aplikasi CSR (Corporate Social Responsibility). Gresik: Fascho Publishing.

Widiyanarti T. 2005. Corporate sosial responsibility : Model comunity development. Jurnal Antropologi Sosial Budaya. Vol 1 dan 2. USU: LPM ANTROP-FISIP. 